\title{
MANAJEMEN USAHA HOME INDUSTRY DESA SINDANGSARI KECAMATAN SUKASARI KABUPATEN SUMEDANG
}

\author{
Dini Rochdiani, Rani Andriani Budi Kusumo, Sulistyodewi Nur Wiyono, \\ Sara Ratna Qanti, dan Agriani Hermita Sadeli \\ Departemen Sosial Ekonomi Pertanian, Fakultas pertanian, Universitas Padjadjaran \\ E-mail: dini.rochdiani@yahoo.co.id
}

\begin{abstract}
ABSTRAK. Desa Sindangsari Kecamatan Sukasari Kabupaten Sumedang, Jawa Barat memiliki potensi sumber daya yang cukup besar sebagai penghasil industri skala rumah tangga potensial khususnya produk makanan olahan. Walaupun memiliki sumber daya yang cukup besar dan merupakan daerah potensial pengembangan industri rumah tangga, masih banyak pelaku industri rumah tangga yang masih melaksanakan usahataninya dengan sangat sederhana dari sisi manajemen dan sisi produksi dengan produk yang tidak memiliki kekhasan, dan belum memiliki diversifikasi produk. Berdasarkan hal tersebut, maka pelatihan mengenai diversifikasi produk olahan dan managemen usaha khususnya managemen usaha industri skala rumah tangga diharapkan akan dapat memberikan kontribusi positif terhadap masyarakat di Desa Sindangsari melalui peningkatan taraf hidup masyarakat. Penyuluhan, pelatihan, dan diskusi kelompok adalah metode pembelajaran yang akan digunakan dalam program Pengabdian Kepada Masyarakat ini. Program ini meningkatkan pengetahuan dan strategi dalam berwirausaha serta meningkatkan nilai tambah pada produk olahan yang sudah ada saat ini.
\end{abstract}

Kata Kunci: home industry, nilai tambah, strategi berwirausaha.

\section{HOME INDUSTRY BUSINESS MANAGEMENT AT SINDANGSARI VILLAGE SUKASARI SUBDISTRICT SUMEDANG DISTRICT}

\begin{abstract}
Sindangsari village Sukasari District, Sumedang, West Java has potential resource as a large potential of household scale industrial producer, especially for processed food products. Although it has a large resource and a potential area of domestic industry development, many industry players are carrying out household business with no uniqueness and no product differentiation, also run the business with low quality management. Therefore, training of processed product diversification and business management especially household scale industries are expected to contribute in increasing living standar of community in Sindangsari village. Counseling, training, and group discussion is a learning method that used in the community services program. This program improve knowledge and strategies in entrepreneurship and increase the value-added processed products.
\end{abstract}

Keywords: home industry, value added, entrepreneurship strategy.

\section{PENDAHULUAN}

Desa Sindangsari Kecamatan Sukasari Kabupaten Sumedang, Jawa Barat merupakan desa sentra produksi pertanian. Komoditas unggulannya antara lain padi dan palawija. Lokasi yang dekat dengan pasar menjadi kekuatan dalam strategi pelaku usaha di Desa Sindangsari. Mata pencaharian penduduk pada umumnya di sektor pertanian dan industri rumahtangga dengan produk olahan pangan.

Memiliki potensi sumber daya alam dan sumber daya manusia yang cukup besar ternyata belum mampu membuat tingkat perekonomian desa yang merata. Hal ini ditunjukkan adanya kesenjangan ekonomi yang cukup besar di masyarakat. Kondisi ini bisa disebabkan oleh banyak faktor, diantaranya adalah kurangnya pengetahuan serta keterampilan penduduk desa dalam memanfaatkan potensi sumber daya (baik sumber daya alam maupun sumber daya manusia) yang ada.

Dalam hal pemanfaatan sumber daya alam ini tentu erat hubungannya dengan pengusahaan sumberdaya tersebut menjadi bahan-bahan yang memiliki nilai atau manfaat yang lebih tinggi. Manfaat yang lebih tinggi itu bisa diperoleh jika masyarakat memiliki pengetahuan, keterampilan, dan mental berwirausaha. Pengetahuan dan keterampilan untuk menambah nilai terhadap suatu produk, khususnya produk pertanian, dapat meningkatkan nilai jual produk tersebut.

Salah satu usaha untuk meningkatkan minat masyarakat yang bergerak di sektor pertanian dan menciptakan hasil yang optimal adalah dengan menggerakan sektor usaha potensial daerah tersebut. Oleh karenanya diperlukan wirausaha-wirausaha yang mampu mengali potensi daerah setempat. Usaha bisnis yang ada perlu ditingkatkan dan melibatkan lebih banyak pelaku. Hal ini menyebabkan upaya membangkitkan jiwa wirausaha sangat diperlukan.

Kemampuan wirausaha dapat tumbuh karena adanya bakat yang dimiliki (innate) maupun oleh dorongan/tuntutan kebutuhan hidup. Oleh karenanya pendidikan (baik formal maupun non formal) kewirausahaan dapat menjadi stimulus bagi banyak orang untuk terlibat dalam usaha tersebut.

Usaha rumah tangga/industri kecil yang ditekuni masyarakat diantaranya pengolahan bahan baku setempat yang mengolah berbagai macam produk seperti makanan dari olahan tepung (tepung terigu, tepung tapioca dan tepung kanji) yang masih bersifat tradisional. Usaha ini termasuk kedalam golongan Usaha Kecil dan Mengah (UKM) yang memiliki karakteristik tertentu. 
Berdasarkan UU No. 9 tahun 1995, usaha kecil dan menengah memiliki kriteria sebagai berikut: (1) Kekayaan bersih paling banyak Rp 200 juta tidak termasuk tanah dan bangunan tempat usaha; (2) Memiliki hasil penjualan tahunan paling banyak Rp 1 miliar; (3) Milik Warga Negara Indonesia (WNI); (4) Berdiri sendiri, bukan merupakan anak perusahaan atau cabang perusahaan yang dimiliki atau dikuasai usaha besar; (5) Bentuk usaha orang per orang, badan usaha berbadan hukum/tidak, termasuk koperasi (6) Untuk sektor industri, memiliki total aset maksimal Rp 5 miliar. Untuk sektor non industri, memiliki kekayaan bersih paling banyak Rp 600 juta (tidak termasuk tanah dan bangunan tempat usaha), atau memiliki hasil penjualan tahunan maksimal Rp 3 miliar pada usaha yang dibiayai.

Disisi lain, Stanley dan Morse (1965) menyatakan bahwa terdapat beberapa karakteristik dari industri kecil, yaitu: (1) Tingkat spesialisasi manajemen relatif rendah, yaitu one man management (manajemen tunggal), dan pemilik merangkap manajer: bidang produksi, keuangan, pembelian, personal, penjualan, dll; (2) Kontak pribadi antar karyawan lebih erat, yaitu hubungan kuat didasari atas hubungan kekeluargaan dengan kualitas hubungan yang dekat dan memperhatikan flesibilitas dalam pekerjaan sehari-hari; (3) Kesulitan dalam mendapatkan modal maupun kredit, tercermin dari usaha yang tidak dapat meningkatkan modal dalam pasar yang terstruktur sehingga diperlukan bantuan institusi keuangan; (4) Jumlah relatif lebih banyak (dibandingkan dengan Industri Menengah dan Besar).

Sedangkan Kuncoro (2007) menjelaskan lebih rinci mengenai karakteristik industri kecil sebagai berikut: (1) Tidak adanya pembagian yang jelas antara bidang administrasi dan operasi; (2) Dikelola secara perorangan, merangkap sebagai pemilik, sekaligus pengelola perusahaan; (3) Memanfaatkan tenaga kerja keluarga dan/atau kerabat dekat; (4) Rendahnya akses industri terhadap lembaga kredit formal, sehingga biasanya IKM sering menggunakan modal sendiri atau sumber lain seperti dari keluarga, kerabat, pedagang, rentenir; (5) Belum memiliki status bahan hukum.

Berdasarkan karakteristik usaha kecil di atas, terdapat beberapa kelemahan dari usaha kecil, yaitu: modal terbatas, kredibilitas rendah, permasalahan pegawai yang biasanya memiliki kapasitas dan ptoduktivitas yang rendah, tingginya biaya langsung, dan keterbatasan kualitas produk. Akan tetapi selain memiliki kekurangan, usaha kecil juga memiliki beberapa kekuatan diantaranya: terdapat sentuhan pribadi, memiliki motivasi yang lebih tinggi, fleksibilitas tinggi, minimnya birokrasi, melatani pasar local/domestic, produk/jasa yang umum.

Terdapat beberapa kompetensi yang dapat menjadikansuatuusahakecilmenjadisukses, diantaranya adalah memiliki pengetahuan dan keterampilan usaha. Pengetahuan adalah pemahaman tentang sebuah subjek yang diperoleh melalui pengalaman atau pembelajaran (belajar dari komunitas, mengetahui apa yang sedang terjadi, melalui pendidikan, belajar dalam pekerjaan).

Salah satu upaya yang dapat dilakukan untuk meningkatkan produk yang dihasilkan oleh UKM di Desa Sindangsari adalah dengan penambahan variasi produk olahan. Hal ini masih perlu ditingkatkan sehingga produk yang dihasilkan lebih bervariatif. Variasi produk dapat dilakukan dengan melakukan diferensiasi produk. Definisi produk menurut Kotler (2000) adalah segala sesuatu yang ditawarkan ke suatu pasar untuk memenuhi kebutuhan atau keinginan. Amir (2005), menambahkan bahwa produk adalah sebuah benda atau pelayanan yang ditawarkanuntuk memenuhi kebutuhan dan kepuasan konsumen.

Dalam konsep produk, konsumen cenderung lebih menyukai produk yang berkualitas dan mempunyai prestasipalingbaik. Konsep produkmemusatkan perhatian pada usaha untuk menghasilkan produk yang lebih unggul dibanding yang lain danmenyempurnakannya secara terus menerus (Suyanto, 2007). Konsep produk berpegang teguh pada anggapan bahwa konsumen akan menyenangi produkyang menawarkan mutu, penampilan, dan keistimewaan dibandingkan produk yang sejenis. Oleh karena itu, organisasi perlu mengadakan perbaikanperbaikan dan strategi produk yang sesuai dengan keadaan pasar (Fuad dkk, 2000).

Keputusan yang berkaitan dengan variable produk dapat dijadikan alat oleh produsen dalam kegiatan pemasaran produknya untuk mengkomunikasikan variable produk sesuai keinginan konsumen, sehingga akan menimbulkan persepsi tertentu pada konsumen yang mengkonsumsi produk tersebut. Salah satu keputusan variable produk yang penting adalah keputusan mengenai atribut produk, yaitu kualitas produk, fitur produk, dan desain (Kotler dan Amstrong, 2001).

Kartajaya (2004) dan banyak pakar manajemen pemasaran mendefinisikan diferensiasi sebagai semua upaya untuk menciptakan perbedaan di antara para pesaing dalam rangka membentukvalue terbaik kepada pelanggan. Inovasi diperlukan untuk mencapai diferensiasi yang kokoh. Terdapat berbagai inovasi yang bisa diterapkan, yaitu: inovasi produk dan layanan, inovasi strategi ataupun inovasi model bisnis.

Hitt, Ireland, dan Hoskisson (2001) menyatakan bahwa diferensiasi adalah serangkaian tindakan integrative yang dirancang untuk memproduksi barang dan jasa yang dianggap para pelanggan berbeda dalam hal-hal yang penting bagi mereka. Dengan strategi diferensiasi, atribut dan karakteristik unit dari produk produsen memberikan nilai bagi pelanggan, karena diferensiasi produk memuaskan kebutuhan unit pelanggan. Tujuan diferensiasi menurut Hitt, Ireland, dan Hoskisson (2001) adalah mengembangkan positioning yang tepat sesuai keinginan potensial yang ingin dituju jika pasar melihat perbedaan produk dibandingkan produk pesaing akan 
lebih mudah mengembangkan marketing mix untuk produk tersebut. Diferensiasi produk yang berhasil adalah diferensiasi yang mampu mengalihkan bisnis persaingan dari harga ke faktor lain, seperti karakteristik produk, strategi distribusi atau variable promotif lainnya.

Kotler (2005) menjelaskan bahwa diferensiasi lebih dari sekedar penetapan posisi yang mengikat perbedaanperbedaan rumit yang mewarnai produk itu sendiri. Diferensiasi didefinisikan sebagai proses menambahkan serangkaian perbedaan yang penting dan bernilai, guna membedakan tawaran dari tawaran pesaing. Diferensiasi akan kuat jika memenuhi kriteria sebagai berikut: penting (memberikan manfaat yang sangat bernilai bagi cukup banyak pembeli), khas (diberikan melalui cara yang khas), unggul (perbedaan yang unggul dibandingkan cara lain untuk memperoleh manfaat dari produk), sulit ditiru oleh pesaing, harga terjangkau, menghasilkan laba.

Terdapat beberapa dimensi dalam diferensiasi yaitu diferensiasi produk, pelayanan, personil, saluran, dan diferensiasi citra (Kotler, 2005). Kertajaya (2004) menyatakan bahwa untuk mendapatkan diferensiasi yang kokoh. Perusahaan harus berkonsentrasi pada tiga dimensi diferensiasi, yaitu konten (dimensi diferensiasi yang menunjukkan valueyang ditawarkan kepada pelanggan dan merupakan bagian tangible dari diferensiasi), konteks (dimensi yang menunjuk pada cara perusahaan menawarkan produk. Ini berhubungan dengan upaya perusahaan untuk membantu konsumen mempersepsikan suatu tawaran dengan cara berbeda dari tawaran pesaing), dan infrastruktur (teknologi, SDM, fasilitas yang digunakan untuk menciptakan diferensiasi content dan konteks).

Setiapproduksecarafisikmemilikipotensikeunikan yang berbeda-beda. Ada produk yang memungkinkan sedikit variasi, namun ada juga yang memiliki diferensiasi produk yang tinggi. Untuk mendiferensiasikan suatu produk, produsen dapat menggunakan berbagai parameter yang mencakup bentuk, fitur, kinerja, kesesuaian mutu dengan standar, daya tahan, keandalan, kemudahan untuk diperbaiki, gaya, dan rancangan.

Untuk menambah variasi melalui diferensiasi produk tersebut maka diperlukan pengetahuan dan keterampilan sumber daya manusia masyrakat Desa Sindanglaya dalam pengolahannya produk yang dihasilkan. Namun, kemampuan berproduksi produk yang baik saja belum cukup untuk menghasilkan keuntungan, manajemen usaha yang baik, serta pengetahuan mengenai peluang pasar yang dimiliki pengusaha akan mempengaruhi perolehan keuntungan tersebut.

Oleh karenanya para pengusaha juga harus memiliki kemampuan dalam mengatur dan mengalokasikan seluruh sumber daya yang dimiliki menjadi output yang bisa memberikan keuntungan maksimal dan berkelanjutan. Untuk mendorong tumbuhnya dunia usaha diperlukan suatu pelatihan business skill yang mengkombinasikan beberapa kegiatan, diantaranya: peningkatan pengetahuan dan keterampilan pengolahan dan diferensiasi produk dan peningkatan pengetahuan dan kemampuan dalam managemen usaha. Hal ini memberikan peluang bagi kami untuk melaksanakan program Pengabdian Kepada Masyarakat di Desa Sindangsari, dengan mengambil sasaran ibu-ibu PKK dan pelaku usaha untuk diberikan pelatihan mengenai penambahan nilai dan diversifikasi produk terhadap produk pangan olahan yang dihasilkan oleh masyarakat di Desa Sindangsari.

Masalah yang dihadapi masyarakat Desa Sindangsari adalah:

1. Bagaimana cara meningkatkan pengetahuan masyarakat Desa Sindangsari mengenai diversifikasi produk olahan makanan?

2. Bagaimana cara meningkatkan pengetahuan dan kemampuan manajemen usaha skala kecil industri rumah tangga bagi masyarakat Desa Sindangsari?

Tujuan dari kegiatan ini adalah:

1. Memberikan pengetahuan kepada masyarakat/ pelaku usaha skala kecil di Desa Sindangsari mengenai diversifikasi produk olahan.

2. Memberikan pengetahuan kepada masyarakat/pelaku usaha skala kecil di Desa Sindangsarimengenai managemen usaha skala kecil/skala rumah tangga.

\section{METODE}

Metoda yang digunakan berupa pelatihan melalui penyuluhan atau ceramah, diskusi dan pelatihan praktek pembuatan/pengolahan produk. Komposisi penyuluhan atau ceramah, praktek, dan diskusi menggunakan waktu yang lebih banyak, baik dalam proses penyuluhannya maupun di luar jadwal tersebut, misalnya para penyuluh siap ditanya para anggota peserta penyuluhan, kapan saja dan dimana saja baik langsung maupun tidak langsung.

Partisipasi masyarakat dalam kegiatan ini adalah sebagai peserta yang terlibat langsung baik sebagai pelaku usaha kecil, pemerhati ataupun berperan sebagai nara sumber permasalahan yang mereka hadapi dan narasumber kepemilikan potensi sumberdaya baik alam maupun keterampilan. Dalam pelaksanaan PKM ini, peserta berperan aktif dalam mengikuti seluruh kegiatan baik itu pre test, pemaparan materi, sesi diskusi dan praktek, maupun sesi post test.

Penyuluhan dan praktek mengelola usaha dilakukan oleh tim pengabdian masyarakat meliputi materi diversifikasi produk dan manajemen usaha skala kecil dan rumah tangga, materi pendukung mengenai Produk Industri Rumah Tangga (PIRT), dan selanjutnya diadakan diskusi antara peserta dengan penyuluh.

Keterampilan yang mudah diserap oleh masyarakat adalah keterampilan yang sifatnya dekat dengan mereka, dalam arti keterampilan yang tidak asing bagi mereka namun memerlukan pembinaan lebih lanjut. Seperti halnya usaha pengolahan bahan pangan. Pembinaan 
yang seyogyanya dilakukan dalam usaha pengolahan meliputi kualitas dan kuantitas cara pengolahan, sehingga mereka dapat menerapkan sesuai dengan daya dukung yang mereka punya beserta kelebihannya. Marta \& Tensiska (2013) juga menyebutkan bahwa potensi yang terdapat di masyarakat perlu dioptimalkan melalui proses pemberdaayaan agar mendorong terciptanya kemandirian masyarakat.

\section{HASIL DAN PEMBAHASAN}

Pelaksanaan program ini dilakukan dalam upaya memberikan pengetahuan kepada masyarakat/pelaku usaha skala kecil di Desa Sindangsari mengenai diversifikasi produk olahan dan managemen usaha skala kecil/ skala rumah tangga. Program ini juga bertujuan untuk memberikan pengetahuan kepada masyarakat mengenai ijin PIRT yang menjadi salah satu syarat penting dalam usaha industri rumah tangga. Dengan adanya program ini, diharapkan bahwa potensi yang sudah ada di Desa Sindangsari, yaitu produk olahan pangan khususnya chees stick, bisa menjadi semakin berkembang.

Program ini diawali dengan pre test, penyampaian materi, diskusi, praktek, dan post test. Penyampaian materi dilakukan dalam 4 sesi yang meliputi penyampaian materi mengenai managemen usaha dan diferensiasi produk, perkenalan Produk Industri Rumah Tangga (PIRT), kemasan, dan praktek pembuatan cheese stick aneka rasa.

a. Penyuluhan Manajemen dan Differensiasi Produk Dalam sesi pertama, materi yang disampaikan adalah mengenai manajemen usaha dan diferensiasi produk yang meliputi definisi, arti penting dan manfaat, serta tahapan-tahapannya. Pemberian materi dilakukan dengan metode ceramah dan diskusi dua arah.

b. Penyuluhan Produk Industri Rumah Tangga

Sesi kedua adalah penyampaian mengenai PIRT. Materi yang disampaikan adalah materi yang disampaikan untuk menindaklanjuti materi yang disampaikan pada sesi kesatu, dimana PIRT ini termasuk salah satu syarat yang harus dipenuhi dalam memasarkan produk olahan rumah tangga. Materi yang disampaikan meliputi definisi, arti penting dan manfaat, serta tahapan dan cara memperoleh nomor PIRT. Pemberian materi dilakukan dengan metode ceramah dan studi kasus dan dilanjutkan dengan diskusi dua arah. Dalam sesi ini, para peserta mengikuti dengan antusias yang dapat dilihat dari banyaknya pertanyaan yang muncul dari peserta kepada pemateri.

c. Penyuluhan Atribut Produk Kemasan

Sesi ketiga adalah penyampaian materi mengenai kemasan dari produk olahan potensi Desa Sindangsari. Untuk menindaklanjuti materi di sesi kesatu dan kedua, sesi ketiga membahas mengenai bagaimana tampilan suatu produk dapat memberikan nilai tambah terhadap produk tertentu yang dapat meningkatkan penjualan baik dari segi kuantitas maupun harga jual. Hasil kegiatan yang dilakukan oleh Saidah et al (2016) menunjukkan atribut produk yang menarik mampu mendorong peningkatan nilai produk yang dipasarkan. Dalam sesi ini peserta diberikan contoh langsung dari kemasan yang sesuai dengan produk olahan potensi desa setempat. Seorang peserta yang juga sebagai produsen chees stick terlihat sangat antusias ketika melihat contoh kemasan yang ditampilkan. Sesi ini juga dilaksanakan diskusi dan tanya jawab.

d. Pelatihan Praktek Pembuatan Produk Dengan Nilai Tambah

Sesi keempat adalah pelaksanaan pelatihan praktek pembuatan chees stick aneka rasa. Berdasarkan pengamatan, peserta sudah memiliki kemampuan untuk membuat chees stick karena mereka sudah terbiasa membuat produk ini, tetapi belum menerapkan strategi differensiasi produk agar dapat berhasil dalam bisnis dan memenangkan persaingan. Peserta belum pernah lakukan adalah melakukan inovasi pada produk mereka, salah satunya yaitu mereka belum pernah mencoba resep lain dan belum pernah menambahkan rasa lain untuk chees stick yang mereka produksi.



Gambar 1. Pelaksanaan kegiatan pengabdian

Kondisi saat sebelum dilakukan penyuluhan, diskusi dan pelatihan praktek, masyarakat memproduksi produk yang hanya di pasarkan di daerah desa sekitar. Produk dijual dengan menggunakan kemasan seadanya dan ukuran kemasan sekitar 1 sampai dengan 2 ons. Selain itu, harga jual hanya berkisar antara Rp. 3.000,sampai dengan Rp. 5.000,- per kemasan.

Setelah memperoleh penyuluhan ini, diharapkan para peserta bisa melakukan diferensiasi menggunakan kemasan yang lebih baik dan menggunakan no PIRT yang sesuai, sehingga bisa meraih dan memenangkan persaingan di pasar dengan memperluas target pemasaran. Dengan diferensiasi produk, diharapkan dapat meningkatkan nilai dari produk olahan yang diproduksi peserta pada khususnya dan masyarakat desa pada umumnya.

Berdasarkan hasil diskusi, evaluasi dan penggalian informasi lebih dalam selama program ini berlangsung, diperlukan pelatihan dan pendampingan lebih lanjut khususnya di bidang pemerolehan ijin PIRT 
dan pemasaran produk olahan masyarakat. Dengan adanya pelatihan dan pendampingan lebih lanjut, diharapkan peserta bisa memperoleh ijin PIRT dan bisa memasarkan produknya pada lingkup yang luas sehingga bisa meningkatkan kesejahteraan masyarakat di Desa Sindangsari.

Post-test dilaksanakan setelah pemberian materi, diskusi dan prkatek. Secara keseluruhan terdapat peningkatan nilai total dari pretest dan post test. Secara umum, rata-rata skor yang diperoleh adalah 13,75 untuk pretest sementara untuk post test, skor rata-ratanya adalah 22,75. Dengan perincian sebagai berikut:

a. Pemahaman mengenai manajemen usaha

Terjadi peningkatan pengetahuan peserta yang ditunjukkan dengan $75 \%$ peserta menyatakan ragu pada pre-test, berubah menjadi tahu pada post test. $25 \%$ dari tidak tahu di pretest menjadi tahu di posttest.

b. Pemahaman mengenai diversifikasi produk $50 \%$ dari keseluruhan peserta menjawab ragu di pretest menjadi tahu di post-test, dan 50\% menjawab tidak tahu di pre-test menjadi tahu di post-test.

c. Pengalaman membuat cheestick

$25 \%$ dari keseluruhan menyatakan pernah di pretest dan pernah di post-test, $50 \%$ menyatakan tidak pernah menjadi pernah, dan $25 \%$ menyatakan ragu ke pernah.

d. Pemahanan menyusun rencana bisnis Peningkatan jumlah peserta yang menjadi tahu yaitu $75 \%$ menyatakan ragu menjadi tahu, dan $25 \%$ menyatakan tidah tahu menjadi tahu.

e. Pengalaman menyusun rencana bisnis

$75 \%$ dari keseluruhan peserta menyatakan tidak pernah menjadi pernah dan 25\% menyatakan tetap tidak pernah.

f. Pengetahuan mengenai PIRT

$25 \%$ dari keseluruhan peserta menjawab pernah di pre-test dan post-test, $50 \%$ menjawab tidak pernah di pre-test dan pernah di post-test, dan $25 \%$ menyatakan ragu di pre-test menjadi pernah di post-test.

g. Pemahaman tentang manfaat PIRT dan tahapannya $25 \%$ dari keseluruhan peserta menjawab ragu di pre-test menjadi paham di post-test, $50 \%$ menjawab paham di pre-test dan post-test, dan $25 \%$ menjawab tidak paham di pre-test dan post-test.

Data diatas menunjukan keberhasilan dari pelaksanaan kegiatan pengabdian kepada masyarakat, dimana para peserta mengalami peningkatan pengetahuan dan keterampilan.

\section{SIMPULAN}

Kegiatan pengabdian kepada masyarakat ini dapat terlaksana dengan baik dan memberikan dampak yang besar sesuai dengan maksud dan tujuan dari pelaksanaan program ini. Hal ini terlihat dari adanya peningkatan pengetahuan (aspek kognitif) peserta mengenai managemen usaha, diversifikasi produk, PIRT, dan pengemasan produk. Selain itu, dari segi afektif, muncul keinginan para peserta untuk memperbaiki cara mereka berusaha. Dari segi psikomotoris, peserta secara langsung mempraktikan bagaimanan cara membuat produk chees stick aneka rasa.

Berdasarkan hasil diskusi, evaluasi dan penggalian informasi lebih dalam selama program ini berlangsung, diperlukan pelatihan dan pendampingan lebih lanjut khususnya di bidang pemerolehan ijin PIRT dan pemasaran produk olahan masyarakat. Dengan adanya pelatihan dan pendampingan lebih lanjut, diharapkan peserta bisa memperoleh ijin PIRT dan bisa memasarkan produknya pada lingkup yang luas sehingga bisa meningkatkan kesejahteraan masyarakat di Desa Sindangsari.

\section{DAFTAR PUSTAKA}

Amir, M. T. 2005. Dinamika Pemasaran. Jakarta: PT. Raja Grafindo Persada.

Hitt, Ireland, Hoskisson. 2001. Competing for Advantage. South Western: Cengange Learning.

Kartajaya, H. 2004. Hermawan Kartajaya on Differentiation. Bandung: Mizan.

Kotler, P. 2000. Marketing Management ed. 10. Indiana: Prentice Hall.

2005. Manajemen Pemasaran. Jakarta: PT. Indeks Kelompok Gramedia.

Kotler, P. dan Amstrong, G. 2001. Principles of Marketing: 9th Edition. New Jersey: Prentice Hall International.

Kuncoro, M. 2007. Ekonomika Industri Indonesia: Menuju Negara Industri Baru 2030? Jogyakarta: Penerbit Andi.

Marta, H dan Tensiska. Pembuatan berbagai produk ubi jalar daam upaya diversifikasi pangan dan peningkatan gizi masyarakat I Desa Sekarwangi dan Desa Cilangkap Kecamatan Buahdua Kabupaten Sumedang. Jurnal Dharmakarka 5(1) : 85-92.

Saidah, Z, Djuwendah E dan Utami, H.U. 2016. Peningkatan costumer value melalui inovasi komoditas kacang tanang sebagai alternatif produk olahan pangan local (oncom Pasireungit) di Kecamatan Paseh, Sumedang. Jurnal Dharmakarya 5 (1) : 47-55

Suyanto, M. 2007. Marketing Strategi Top Brand Indonesia. Yogyakarta: Penerbit Andi. 